\title{
Comparison of Off-line and On-line Measurement of Partial Discharges for Hydrogenerator Stator Windings using Acoustic Emission Sensors
}

\author{
Tadamitsu Kaneko Member (Miyazaki Municipal University, kaneko@miyazaki-mu.ac.jp) \\ Takashi Ueda Student Member (Miyazaki University, ueda@epl.opt.miyazaki-u.ac.jp) \\ Osamu Takenouchi Member (Civil Aviation College, take@kouku-dai.ac.jp) \\ Masahisa Otsubo Member (Miyazaki University, otsubo@cc.miyazaki-u.ac.jp) \\ Chikahisa Honda Member (Miyazaki University, honda@cc.miyazaki-u.ac.jp) \\ Yoshio Tsuruta Non-member (Kodensya Co., Ltd., y-turuta@kodensya.co.jp) \\ Hideki Iwamoto Non-member (Kyushu Electric Power Co. Inc., Hideki_Iwamoto@kyuden.co.jp) \\ Akihiro Tokumitsu Non-member (Kyushu Electric Power Co. Inc., Akihiro_Tokumitsu@kyuden.co.jp)
}

Keywords: condition based maintenance,insulation diagnosis, hydrogenerator stator windings, partial discharge, acoustic emission detection method

The establishment of Condition Based Maintenance for hydrogenerators is very important for monitoring the conditions of stator windings insulation. On-line partial discharge (PD) testing has been used to provide useful information for monitoring the integrity and diagnosing problems in hydrogenerator stator winding insulation. The on-line insulation diagnosis technology can assess thermal, electric, ambient, and mechanical stresses received by the hydrogenerator stator windings. We have already indicated in a previous study that on-line PD measurements using acoustic emission sensor (AE) techniques can be useful for assessing the conditions of stator winding insulation. In this paper, the relationship between $\mathrm{AE}$ signals and maximum discharge magnitude was investigated in a non-destructive test for hydrogenerators using off-line measurements. AE signals were investigated by the use of multiple AE sensors, which are produced from an internal discharge for two hydrogenerator stator windings in $11 \mathrm{kV}$ and $13.2 \mathrm{kV}$ classes, in addition to the load and temperature, and humidity measurements taken online in twenty-month and three-month long studies respectively.

Figures 1 and 2 show characteristics of intensity of AE versus maximum discharge magnitude (Qmax) at off-line measurements. From a series of experimental results, a relatively good correlation was observed among Qmax and AE signal at off-line measurements.

Figure 3 shows characteristics of intensity of AE signals, humidity and coil temperature at PDs and PDn for I- hydrogenerator $11.0 \mathrm{kV}$ class for three months at on-line measurements. Figure 4 shows characteristics of intensity of AE signals, humidity and coil temperature at PDs and PDn for O-hydrogenerator $13.2 \mathrm{kV}$ class for three months at on-line measurements.

As a result, it was found that the PDs and PDn are varied from $26 \mathrm{~dB}$ to $40 \mathrm{~dB}$ for I-hydrogenerator $11.0 \mathrm{kV}$ class for three months in winter season at on-line measurements. Also, it was

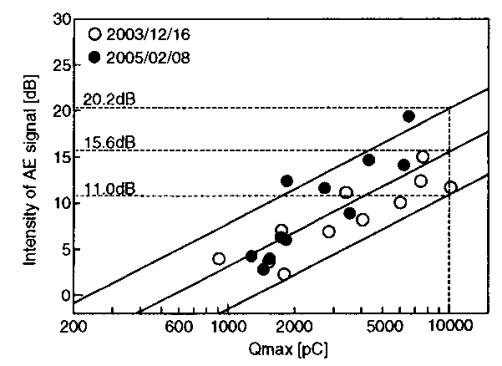

Fig. 1. Characteristics of intensity of AE versus maximum discharge magnitude (Qmax) for I-hydrogenerator $11.0 \mathrm{kV}$ class at off-line measurements found that the PDs and PDn is varied from $15 \mathrm{~dB}$ to $25 \mathrm{~dB}$ for Ohydrogenerator $13.2 \mathrm{kV}$ class for three months in winter season at on-line measurements.

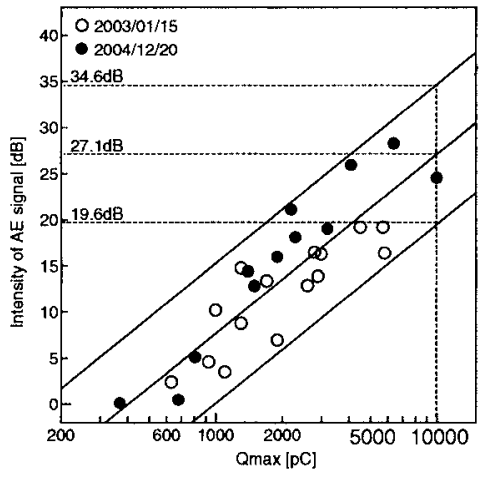

Fig. 2. Characteristics of intensity of AE versus maximum discharge magnitude (Qmax) including standard deviation for O-hydrogenerator $13.2 \mathrm{kV}$ class at off-line measurements

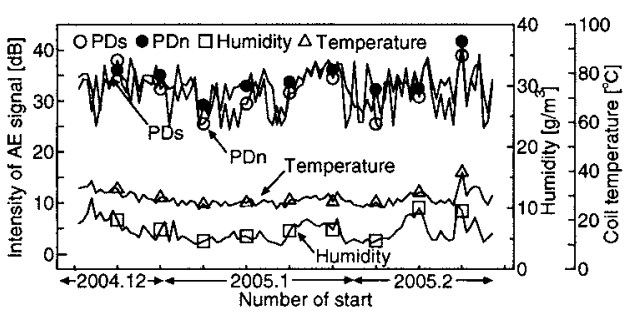

Fig. 3. Characteristics of intensity of AE signals, humidity and coil temperature at PDs and PDn for Ihydrogenerator $11.0 \mathrm{kV}$ class for three months at on-line measurements

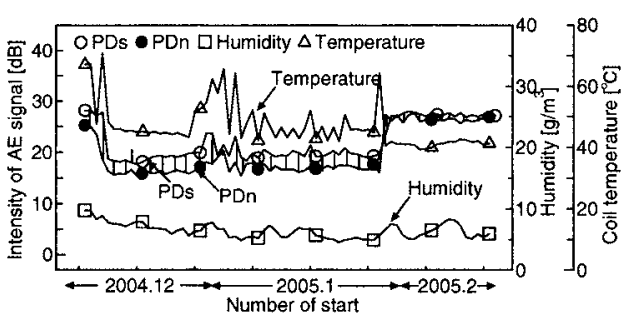

Fig. 4. Characteristics of intensity of AE signals, humidity and coil temperature at PDs and PDn for Ohydrogenerator $13.2 \mathrm{kV}$ class for three months at on-line measurements 


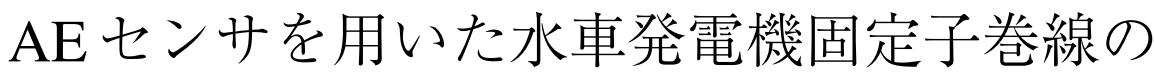 オフライン・オンライン部分放電比較
}

$\begin{array}{lllll}\text { 正 員 金子 正光* } & \text { 学生員 上田 } & \text { 隆司 } \\ \text { ** } \\ \text { 正員 竹之内 修*** } & \text { 正 員 大坪 } & \text { 昌久** } \\ \text { 正 員 本田 親久** } & \text { 非会員 } & \text { 鶴田 } & \text { 芳男**** } \\ \text { 非会員 岩元 秀樹*5 } & \text { 非会員 徳満 } & \text { 明博*5 }\end{array}$

\section{Comparison of Off-line and On-line Measurement of Partial Discharges for Hydrogenerator Stator Windings using Acoustic Emission Sensors}

\author{
Tadamitsu Kaneko*, Member, Takashi Ueda**, Student Member, Osamu Takenouchi***, Member, \\ Masahisa Otsubo** ${ }^{* *}$ Member, Chikahisa Honda**, Member, Yoshio Tsuruta****, Non-member, \\ Hideki Iwamoto*5, Non-member, Akihiro Tokumitsu*5, Non-member
}

The establishment of Condition Based Maintenance for hydrogenerators is very important for monitoring the conditions of stator windings insulation. On-line partial discharge (PD) testing has been used to provide useful information for monitoring the integrity and diagnosing problems in hydrogenerator stator winding insulation. The on-line insulation diagnosis technology can assess thermal, electric, ambient, and mechanical stresses received by the hydrogenerator stator windings. We have already indicated in a previous study that on-line PD measurements using acoustic emission sensor (AE) techniques can be useful for assessing the conditions of stator winding insulation. In this paper, the relationship between $\mathrm{AE}$ signals and maximum discharge magnitude was investigated in a non-destructive test for hydrogenerators using off-line measurements. AE signals were investigated by the use of multiple AE sensors, which are produced from an internal discharge for two hydrogenerator stator windings in $11 \mathrm{kV}$ and $13.2 \mathrm{kV}$ classes, in addition to the load and temperature, and humidity measurements taken on-line in twenty-month and three-month long studies respectively.

キーワード : 状態監視保全, 絶縁診断, 水車発電機固定子巻線, 部分放電, 超音波法

Keywords: condition based maintenance, insulation diagnosis, hydrogenerator stator windings, partial discharge, acoustic emission detection method

\footnotetext{
* 宮崎公立大学人文学部

干 880-8520 宮崎市船塚 1-1-2

Faculty of Humanities, Miyazaki Municipal University

1-1-2, Funatsuka, Miyazaki 880-8520

** 宮崎大学工学部

干 889-2192 宮崎市学園木花台西 1-1

Faculty of Engineering, Miyazaki University

1-1, Gakuen Kibanadai Nishi, Miyazaki 889-2192

*** 航空大学校

880-8580＼cjkstart宮崎市大字赤江字飛江田 652-2

Civil Aviation College

652-2, Aza Hieda, Oaza Akae, Miyazaki 880-8580

**** (株) 興電舎

于 882-0862 延岡市原町 221-1

Kodensya Co., Ltd.

221-1, Hama-machi, Nobeoka 882-0862

$* 5$ 九州電力 (株) 宮崎支店
}

\section{1. はじめに}

近年, 電力会社で直面している電力流通設備に対するコ スト抑制方策の一環として, 発電設備の寿命限界利用と維 持管理コストの低減が最重要課題となっている。水力発電 事業は, 環境にやさしいクリーンなエネルギーの確保とと もに, ダムの放流水, 渓谷の流水等の水資源を有効活用す る観点からも注目されている。

電力消費の昼夜間格差の増大に伴って水車発電機は負荷 調整運転を行っている。起動・停止や負荷変動の頻繁な運 転条件中の水車発電機固定子巻線は熱的, 電気的, 環境的,

于 880-8544 宮崎市橘通西 4-2-23

Miyazaki Branch, Kyushu Electric Power Co., Inc. 4-2-23, Tachibanadouri-Nishi, Miyazaki 880-8544 
機械的 (TEAM : thermal, electrical, ambient, mechanical) ストレスの影響を受けるので，絶縁耐力が経年的に急速に 低下することが知られている ${ }^{(1)}$ 。

水車発電機固定子巻線の余寿命診断法としては，これま で定期的に水車発電機を停止して行う非破壊絶縁試験が実 施されているが，しかしこの非破壊絶縁診断手法は水車発 電機の停止や大掛かりな試験装置を必要とするため, 多大 な日数と費用を要する。さらに，水車発電機固定子巻線に 対し定格電圧より高い電圧を印加するため, 固定子巻線へ の悪影響が懸念される。そのため，オンライン状態で水車 発電機固定子巻線の絶縁最弱点部を検出して, その位置で の絶縁劣化基準を確立して, 水車発電機固定子巻線の寿命 限界利用を検討することが重要である。さらに，絶縁破壊 事故の未然防止及び設備の有効利用などの観点からもオン ラインで水車発電機固定子巻線の絶縁診断法の確立が重要 である。

運転中回転機の部分放電 (PD) 検出の技術課題の一つと して, 電気的ノイズの問題がある。ノイズを避けるため, 運転中 PD 検出はより高周波側で計測される傾向にあるが, 回転機巻線はインダクタンスが大きく, PD パルスが本来有 している高周波成分は巻線伝播する間に減衰することが知 られている。従って，放電発生源とセンサの位置関係も重 要となる。水車発電機固定子巻線の内部で PD が発生した 場合，電気的なパルスと同時に微小音響が発生する。一般 にこれらの音響の周波数領域はかなり広いが，その超音波 成分を検出するのが超音波法である。 $\mathrm{AE}$ センサを用いる $\mathrm{PD}$ 検出手法は，AEセンサ自体を容易に移動して固定子鉄 心に直接取り付けることができるので，放電発生源近くで $\mathrm{PD}$ を測定することができる。また，AEセンサを用いた実 機の水車発電機固定子巻線の PD 特性に関する研究例は少 ない。

PD 検出用のセンサとして既存の測温度抵抗体を用いて 水車発電機運転中でも容易にPD を計測し，固定子巻線の 絶縁状態を間接的に捉えることができる可搬式発電機部分 放電モニターの開発が試みられている(1)。しかし，既存の 測温度抵抗体をセンサとして用いる部分放電検出システム では，水車発電機固定子巻線の絶縁最弱部での PDを検出 することは困難で，水車発電機固定子巻線の絶縁最弱点位 置での絶縁劣化状態のデー夕収集・解析による絶縁劣化判 定基準の確立が最重要課題として注目されている。

著者らは，運転中の発電機に生じる磁気振動や回転子の 回転による機械的なノイズの除去方法を提案し，その有効 性を実証した (2)。また，水車発電機起動直後のPD レベル は大きく変化し, 定常運転時のPDレベルは平均してほぼ 一定であることなどの知見を得た ${ }^{(3)}$ 。さらに，PD信号レベ ルが平均して一定である水車発電機定常運転時に, 超音波 法の利点である $\mathrm{AE}$ センサの取り付け取り外しが容易であ ることを利用して，複数の場所において固定子巻線の PD による AE 波を複数同時に自動計測するシステムを開発し, それを用いて水車発電機固定子巻線における最大 PD の発
生位置を推定した ${ }^{(4)}$ 。しかし，超音波法による水車発電機 巻線絶縁の簡易診断技術の確立には，停止中診断データと 運転中診断データとの相関関係の解明並びに運転中水車発 電機固定子巻線の PD 特性に及ぼす巻線温度（以下，温度 とする）や湿度の外部環境条件の影響の解明が必要である。

そこで，本論文では，複数個の AE センサを用いて実機 の水車発電機 2 台（定格電圧 $11.0 \mathrm{kV}$ と $13.2 \mathrm{kV}$ ) の停止中 診断データの最大放電電荷量と $\mathrm{AE}$ 強度の関係を調べると ともに運転中水車発電機固定子巻線の部分放電特性に及ほ す発電機の出力, 温度そして湿度の影響を調べたので, こ こに報告する。

\section{2. 実験の装置と方法}

表 1 に示すようにエポキシレジン絶縁系の I-発電機（定 格電圧 $: 11.0 \mathrm{kV}$, 定格出力 : $18,600 \mathrm{~kW}$, 固定子巻線の経 年年数：39 年) と $\mathrm{O}$-発電機（定格電圧： $13.2 \mathrm{kV}$, 定格出 力 : $40,500 \mathrm{~kW}$, 固定子巻線の経年年数 : 45 年) を対象に 停止中診断データとして最大放電電荷量と $\mathrm{AE}$ 信号強度の 関係を，また運転中診断データとして起動から定常運転ま での AE 信号強度特性を調べた。I-発電機の冷却方式は, 建 屋内の空気を取り込み巻線などの加熱部分を冷却して風道 から出口管を通り排熱するという出口管通風形である。一 方, O-発電機の冷却方式は, 一次冷媒の通路が外部に対し 閉鎖されその熱は熱交換器内で二次媒体である周囲媒体に 伝達される構造の熱交換器形 1 種である。I-発電機の長期 連続測定を 2003 年 7 月から 2005 年 2 月の期間中, また O-発電機の長期連続測定を 2004 年 12 月から 2005 年 2 月 の期間中に実施した。図 1 に AE センサを用いた水車発電 機の部分放電試験の概略図を示す。また，図 2 に I-発電機 固定子鉄心外枠の垂直方向に固定した複数個の $\mathrm{AE}$ センサ の写真を示す。

連続測定においては, AE 信号を 1 分間毎に測定するとと もに発電機出力, 温度そして湿度も測定した。 $\mathrm{AE}$ 波の計測

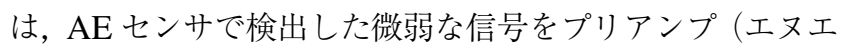
フ回路設計製，形式 9917, 周波数特性 : $2 \mathrm{kHz} \sim 1.2 \mathrm{MHz}$ ) により解析できる十分な值まで増幅された後, A/D コンバー 夕（サンプリング周波数： $250 \mathrm{kHz}$ ) を経由して測定した。

表 1 測定対象の水車発電機の仕様

Table 1. Specifications for the measured hydrogenerators.

\begin{tabular}{c|c|c}
\hline & I-hydrogenerator & O-hydrogenerator \\
\hline Kinds of class & $11.0 \mathrm{kV}$ & $13.2 \mathrm{kV}$ \\
\hline Capacity [kVA] & 20,700 & 45,000 \\
\hline Rated Power [kW] & 18,600 & 40,500 \\
\hline Insulation material & Epoxy & Epoxy \\
\hline Insulationtype & $\mathrm{B}$ & $\mathrm{B}$ \\
\hline Rated voltage [kV] & 11.0 & 13.2 \\
\hline Rated current [A] & 1,087 & 1,970 \\
\hline Poles & 24 & 40 \\
\hline Rated revolution [rpm] & 300 & 180 \\
\hline Recoil [year] & 1966 & 1960 \\
\hline
\end{tabular}




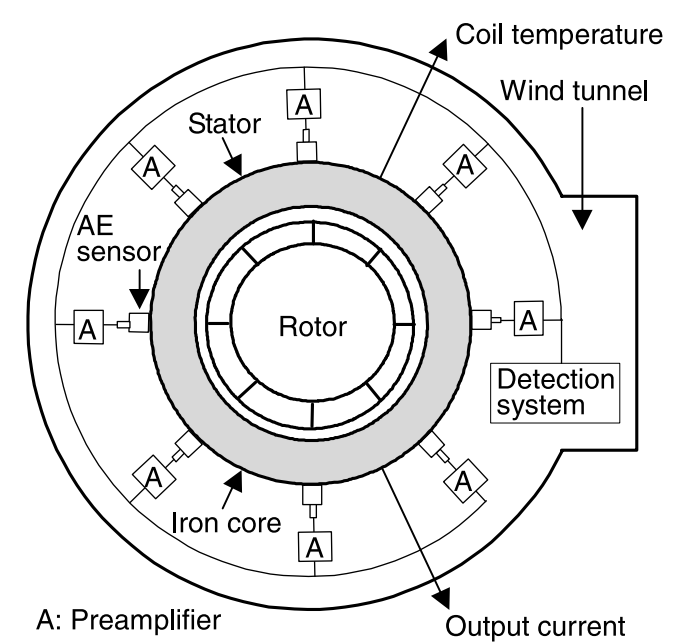

図 $1 \mathrm{AE}$ センサを用いた水車発電機の部分放電 試験の概略図

Fig. 1. Schematic diagram of partial discharge testing for hydrogenerator with $\mathrm{AE}$ sensors.

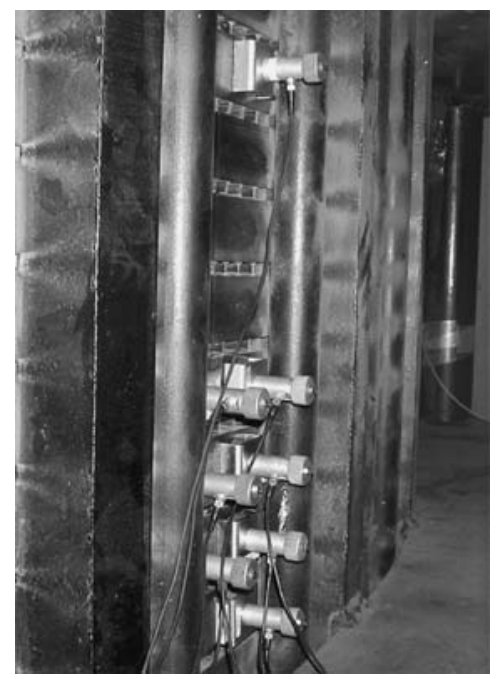

図 2 I-発電機固定子鉄心外枠の垂直方向に 固定した複数個の $\mathrm{AE}$ センサの写真

Fig. 2. Photograph of many AE sensors set on the vertically outer flame of stator iron for I-hydrogenerator.

また，同時に発電機電流をクランプメータで，固定子巻線 の温度を温度測定用抵抗体で測定した。

\section{3. 実験結果と考察}

〈3.1〉 オフライン試験における最大放電電荷量と $\mathbf{A E}$ 信号強度の関係回転機絶縁物の絶縁材料がエポキシ絶 縁の絶縁劣化診断技術はまだ基準として定着するに至って いない。水車発電機の絶縁劣化現象を判定する停止中の絶 縁劣化診断法として, 誘電正接試験や部分放電試験などが 適用されている。部分放電試験は劣化によるクラックや剥 離などの空隙の発生や進展状況より, 絶縁劣化の進行を推 定するのに利用されている。金神らは測温抵抗体を用いて オンライン時の水車発電機の絶縁劣化基準として，オフラ

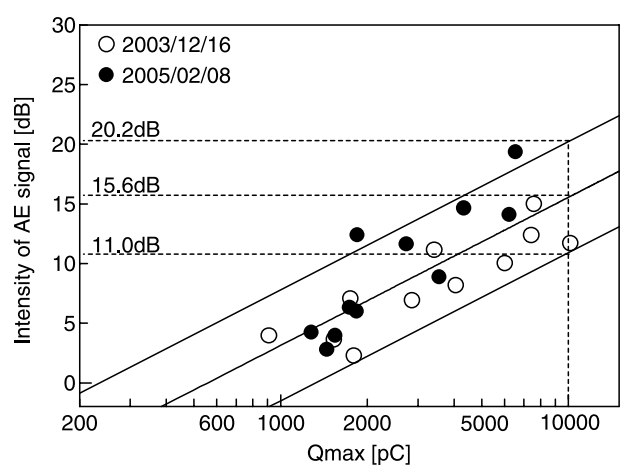

図 3 I-発電機オフライン測定時の $\mathrm{AE}$ 信号強度 対最大放電電荷量 (Qmax) 特性

Fig. 3. Characteristics of intensity of AE versus maximum discharge magnitude (Qmax) for I-hydrogenerator at off-line measurements.

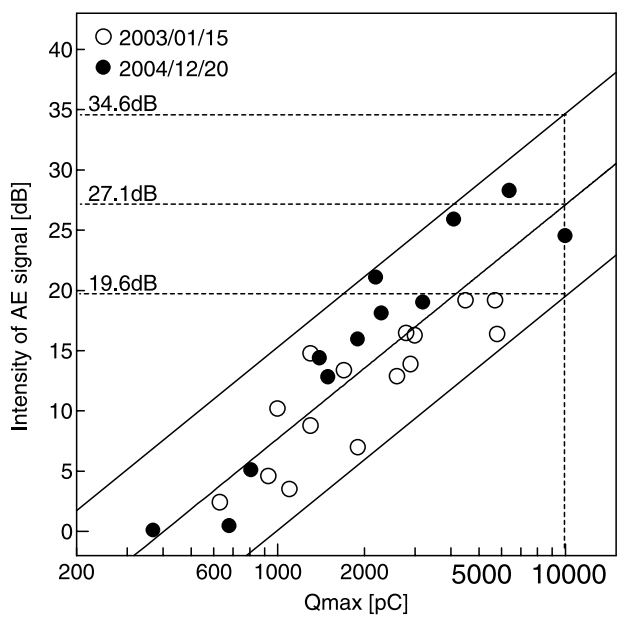

図 4 O-発電機オフライン測定時の $\mathrm{AE}$ 信号強度 対最大放電電荷量 $(\mathrm{Qmax})$ 特性

Fig. 4. Characteristics of intensity of AE versus maximum discharge magnitude (Qmax) for O-hydrogenerator at off-line measurements.

インにおける部分放電試験の最大放電電荷量 $(\mathrm{Qmax})$ を採 用して, $Q \max$ の温度依存性からオンラインの水車発電機 の絶縁劣化判定できる可能性を示している(5)。著者らは電 気的劣化基準と音響的劣化基準を比較検討するために，才 フライン試験に扔ける最大放電電荷量と $\mathrm{AE}$ 信号強度の関 係を調べた ${ }^{(6) \sim(8)}$ 。

I-発電機において PD が最大に発生している付近に複数個 の $\mathrm{AE}$ センサを固定して, 部分放電試験の各印加電圧に対し て AE 信号測定を同時に行った。試験日は 2003 年 12 月 16 日と 2005 年 2 月 8 日で, デー夕をまとめた結果を図 3 に示 す。水車発電機に扔けるオフライン時の $\mathrm{Qmax}=10,000 \mathrm{pC}$ を基準にすると (5)，そのときの平均 $\mathrm{AE}$ 信号強度は $15.6 \mathrm{~dB}$ で, 回帰分析結果より標準偏差 $(\sigma)$ を求めると $\sigma=4.6 \mathrm{~dB}$ となる。O-発電機に対しても PD が発生している箇所に複 数個の $\mathrm{AE}$ センサを固定して，2003 年 1 月 15 日と 2004 年 12 月 20 日に部分放電試験を実施した。その結果を図 4 
に示す。 $\mathrm{Qmax}=10,000 \mathrm{pC}$ を基準にすると，そのときの 平均 $\mathrm{AE}$ 信号強度は $27.1 \mathrm{~dB}$ で, $\sigma=7.5 \mathrm{~dB}$ となる ${ }^{(8)}$ 。こ のように，オフラインとオンラインの部分放電特性を関係 づける水車発電機特有の $\mathrm{AE}$ 信号強度対 Qmax 特性が得ら れた。

$\langle\mathbf{3} \cdot 2\rangle$ オンライン測定時における水車発電機固定子巻 線の部分放電特性

$\langle\mathbf{3 \cdot 2 \cdot 1 \rangle}$ 固定子巻線の $\mathrm{AE}$ 信号強度分布 図 2 に示 したように発電機固定子鉄心の外枠に複数個の $\mathrm{AE}$ センサ を直接固定子鉄心の水平方向と垂直方向に対して $\mathrm{AE}$ センサ 間の距離を変えて取り付け，AE 信号を数回測定した。図 5 に例として I-発電機オンライン測定時における固定子巻線 の垂直方向の AE 信号強度分布を示す。図 6 に I-発電機固 定子巻線の $\mathrm{AE}$ 信号強度分布を示す。この図からわかるよ うに，水平方向で $-0.1 \mathrm{~m}$, 垂直方向で固定子鉄心 10 番目

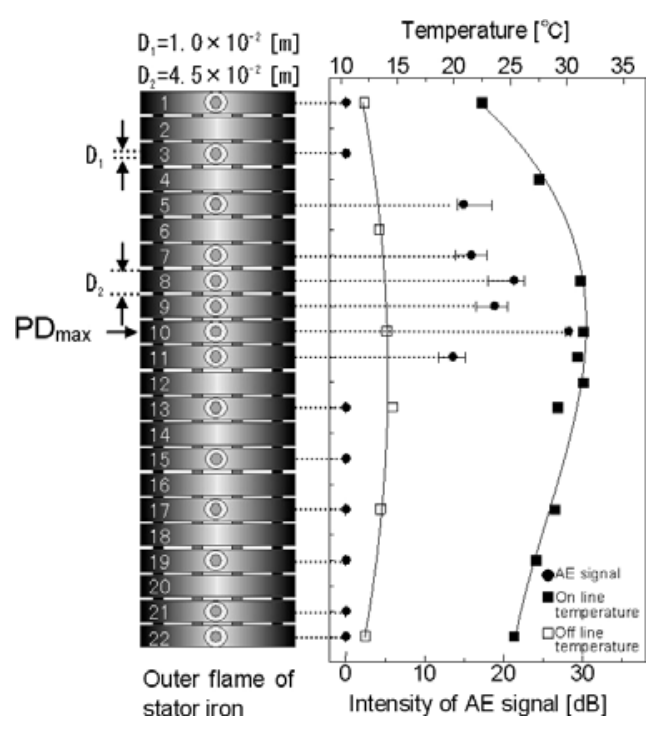

図 5 I-発電機オンライン測定時における 垂直方向の $\mathrm{AE}$ 信号強度分布

Fig. 5. Distribution of AE intensity in vertical position for I-hydrogenerator at on-line measurements.

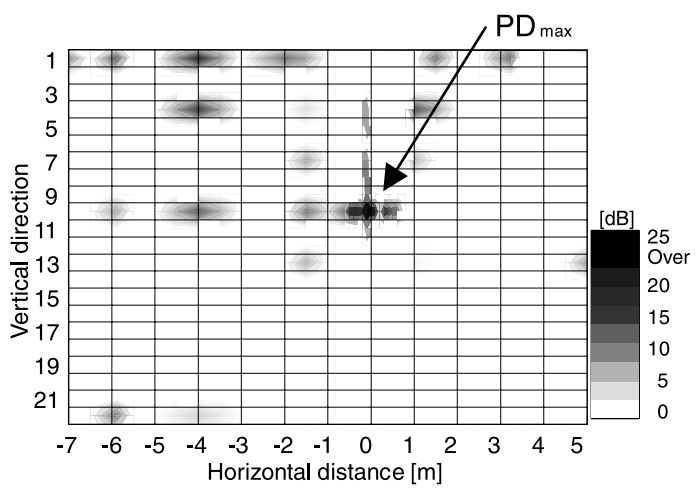

図 6 I-発電機オンライン測定時における 固定子巻線の $\mathrm{AE}$ 信号強度分布

Fig. 6. Distribution of AE intensity for I-hydrogenerator stator windings at on-line measurements.
（図中にPDmax を示す）のバーにおいて最大 PD を検出す ることができた。図 7 に例として O-発電機オンライン測 定時における垂直方向の $\mathrm{AE}$ 信号強度分布を示す。図 8 に O-発電機オンライン測定時における固定子巻線の AE 信号 強度分布を示す。なお，O-発電機の場合は，冷却方式が熱 交換器形 1 種であり， $\mathrm{AE}$ センサの設置ができない場所が あるので，図中には測定できない領域を斜線で示した。こ れらの一連の結果から，オンライン測定時の水車発電機固 定子巻線の PD 特性は TEAM ストレスを複合的に受けて絶 縁劣化するので，固定子巻線の絶縁劣化の場所は複雑に変 化することがわかった。例えば測温抵抗体を用いた電気的 な PD 検出手法の場合, 放電発生源と測温抵抗体の位置関 係が問題となる。しかし，AE センサを用いた PD 検出手

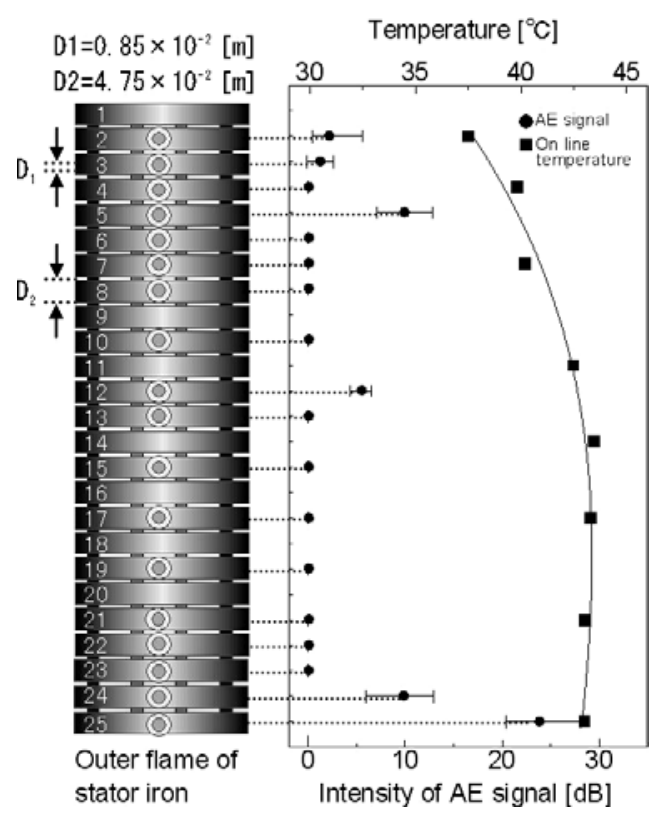

図 7 O-発電機オンライン測定時における 垂直方向の $\mathrm{AE}$ 信号強度分布

Fig. 7. Distribution of AE intensity in vertical position for O-hydrogenerator at on-line measurements.

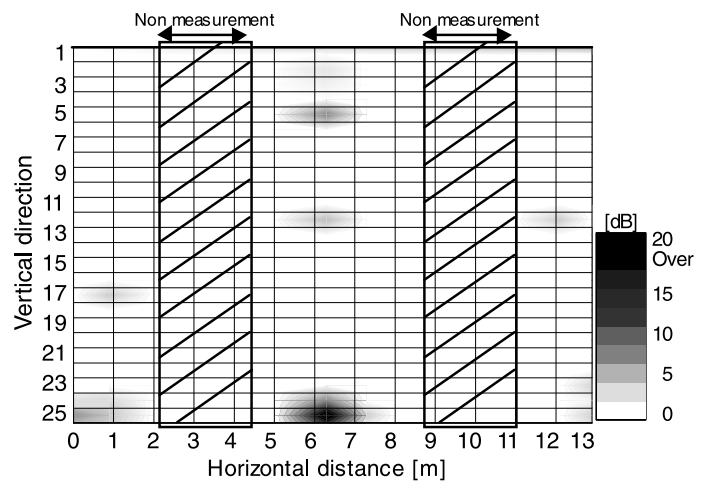

図 8 O-発電機のオンライン測定時における 固定子巻線の $\mathrm{AE}$ 信号強度分布

Fig. 8. Distribution of AE intensity for O-hydrogenerator stator windings at on-line measurements. 


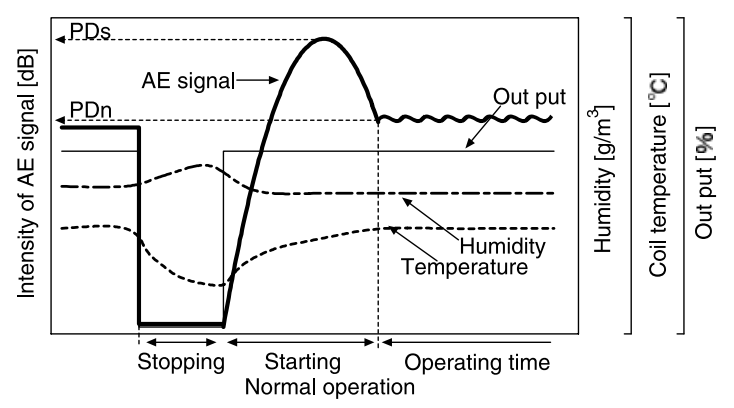

図 9 オンライン測定の起動時における $\mathrm{AE}$ 信号強度に及ぼす出力, 巻線温度と湿度の 影響の概念図

Fig. 9. Conceptual model of intensity of AE signals of PDs and PDn at operatings conditions (output percent, coil temperature and humidity) for hydrogenerator at online measurements.

法は，AE センサを容易に移動して固定子鉄心に取り付け ることができるので, 水車発電機固定子巻線の絶縁の弱点 部を検出する有効な PD 検出手法である。

$\langle\mathbf{3} \cdot \mathbf{2} \cdot \mathbf{2}\rangle$ 長期連続部分放電特性 絶縁診断時に掞い て最も重要な特性である Qmax は，測定条件，例えば，温 度や湿度に大きく依存することが知られている。また，発 電機の起動・停止による負荷電流の変動や季節変動等によ り温度及び Qmax が変動することが知られている(9)。運転 中水車発電機の固定子巻線の部分放電特性については, こ れまで多くの研究者ら (1)によって調べられて，例えば測温 抵抗体を部分放電アンテナとして用いる活線絶縁診断法等 が検討されている。金神氏らは，この手法を適用した部分 放電現場システムを用いて, 4 台の発電機を対象に，約 1 年 間にわたり，Qmax，温度，負荷電流を1時間毎に連続的に 測定・収集して，デー夕の解析を行った。その結果，運転 中水車発電機の固定子巻線の長期部分放電特性が絶縁劣化 診断に役立つことを示している( ${ }^{(9)}$ 。著者らは, I-発電機に関 しては 2003 年 7 月から 2005 年 2 月の期間中，そして O発電機に関しては 2004 年 12 月から 2005 年 2 月の期間中, $\mathrm{AE}$ 信号波形，温度，湿度そして負荷電流を連続測定した。 著者らは, $\mathrm{AE}$ 信号は電源周波数 $(60 \mathrm{~Hz})$ の $1 / 2$ 倍の周期 (8.3 ms) で大きく信号が現れ，そして部分放電の周波数特 性である 20 30 kHz 付近で大きく信号強度が出ているこ とを確認した。著者らのこれまでの研究成果から，図 9 に 示すように起動時の $\mathrm{AE}$ 信号強度は, 起動直後に急激に上 昇しある時刻で最大值を示した後減少し，その後は定常運 転時にはほぼ一定值に落ち着く傾向があることがわかって いる( ${ }^{(3)}$ 。ここで，著者らは同図に示すように起動から 60 分 の間に測定される $\mathrm{AE}$ 信号強度の最大值を PDs，また起動 から 60 分後の定常運転状態に打ける平均 $\mathrm{AE}$ 信号強度を PDn とする。

図 10 にI-発電機の夏場と冬場におけるオンライン測定の $\mathrm{AE}$ 信号強度に及ぼす温度, 湿度そして出力の時系列特性を 示す。特に，ここでは季節による特性比較を行うため，夏

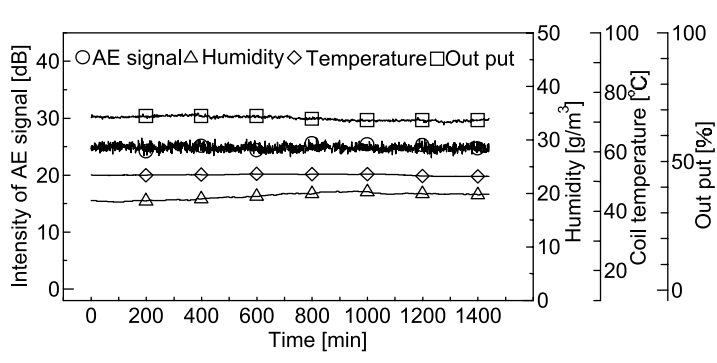

(a-1) $2003 / 08 / 23$

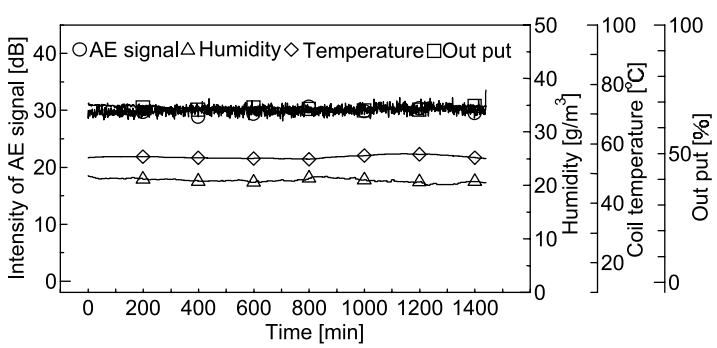

(a-2) $2004 / 08 / 20$

(a) Summer seasons (2003-2004)

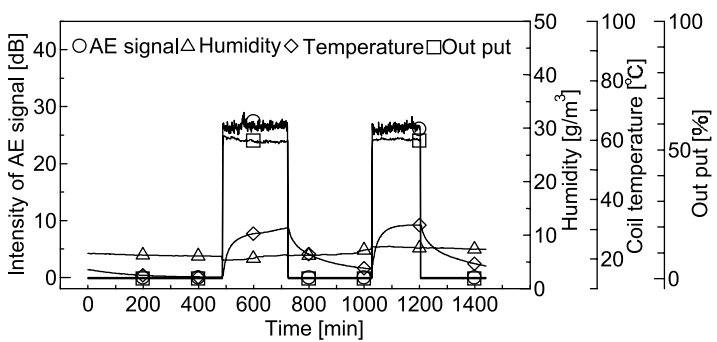

(b-1) $2004 / 01 / 12$

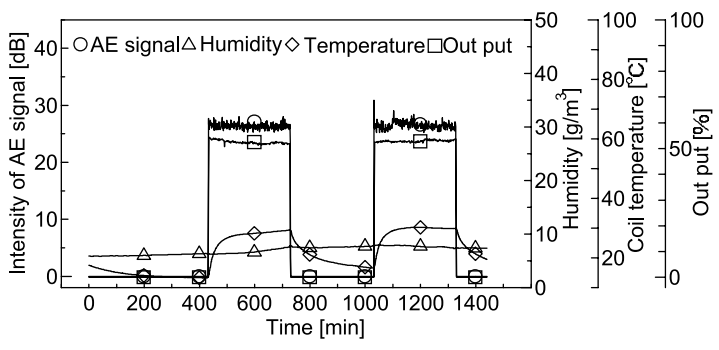

(b-2) $2005 / 01 / 06$

(b) Winter seasons (2004-2005)

図 10 I- 発電機の夏場と冬場に打けるオンライン 測定の AE 信号強度に及ぼす温度，湿度 そして出力の時系列特性

Fig. 10. Time dependence for time dependence for intensity of AE signals, coil temperature, humidity and output percent for I-hydrogenerator for summer and winter seasons at on-line measurements.

場の特性として 2003 年と 2004 年の 8 月（図中 (a) 夏場), そして冬場の特性として 2004 年と 2005 年の 1 月（(図中 （b）冬場）の結果を中心に述べる。このとき，夏場の発電機 出力は $14,000 \mathrm{~kW}$ (定格 $75 \%$ ), そして冬場の発電機出力は $11,000 \mathrm{~kW}$ (定格 59\%）である。これらの図から，夏場にお いて 2004 年の夏の $\mathrm{AE}$ 信号強度レベルは 2003 年の值に比 べて約 $5 \mathrm{~dB}$ 程度の上昇を示す。しかし，冬場における $\mathrm{AE}$ 信号強度の変化が見られなかった。このように, I-発電機の 


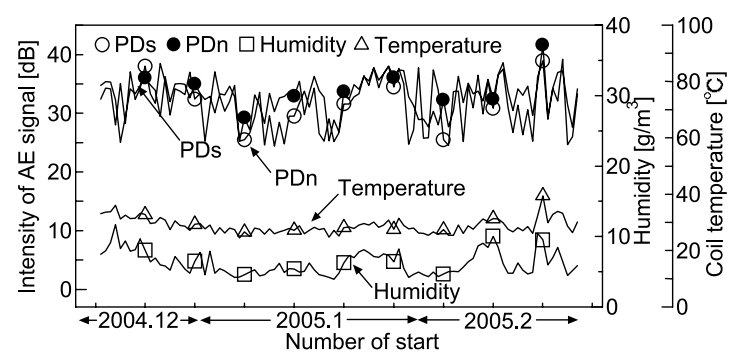

図 11 I-発電機オンライン測定時の PDs と PDn の 3 ケ月間 $\mathrm{AE}$ 信号強度に及ほす温度と 湿度の時系列特性

Fig. 11. Time dependence for intensity of AE signals, coil temperature and humidity at PDs and PDn for Ihydrogenerator for three months at on-line measurements.

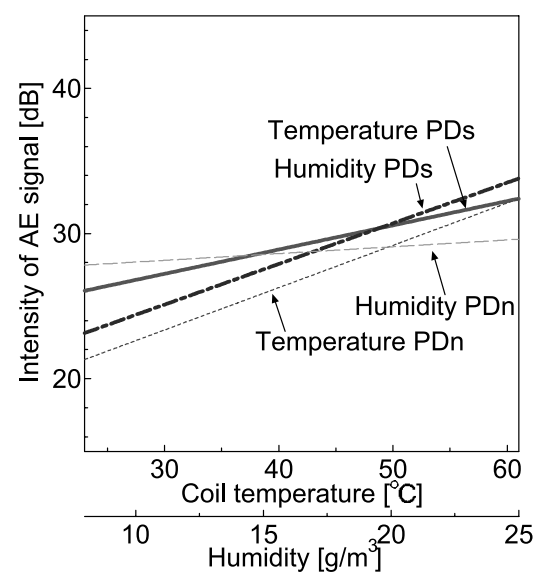

図 12 I-発電機オンライン測定時の AE 信号強度 対温度と湿度の回帰分析

Fig. 12. Regression analysis of AE singnals intensity, coil temperature and humidity for I-hydrogenerator at online measurements.

\section{表 2 I-発電機オンライン測定時の $\mathrm{AE}$ 信号強度 対温度と湿度の相関係数}

Table 2. Correlation coefficent of AE singnals intensity, coil temperature and humidity for I-hydrogenerator at online measurements.

\begin{tabular}{c|c|c}
\hline 特性 & PDs & PDn \\
\hline $\mathrm{AE}$ 信号強度対温度特性 & 0.20 & 0.42 \\
\hline $\mathrm{AE}$ 信号強度対湿度特性 & 0.45 & 0.12 \\
\hline
\end{tabular}

$\mathrm{AE}$ 信号強度は季節によって变化することがわかる。次に 2004 年 12 月から 2005 年 2 月までの約 3 ケ月間の長期連 続測定結果のPD をPDs と PDnに分離して整理した結果 を図 11 に示す。この図から PDs と PDn は 26 40 dB と変 化することがわかる。さらに，I-発電機において，2003 年 と 2004 年の 2 年間の夏場（7 月～9 月）の部分放電のデー 夕を PDs と PDn に区別して $\mathrm{AE}$ 信号強度対温度, 湿度の 回帰直線を求めた。その結果を図 12 に示す。また，その ときの相関倸数を表 2 に示す。これらの結果より，I-発電 機の場合，PDs は湿度に依存するが，PDn は温度に依存す

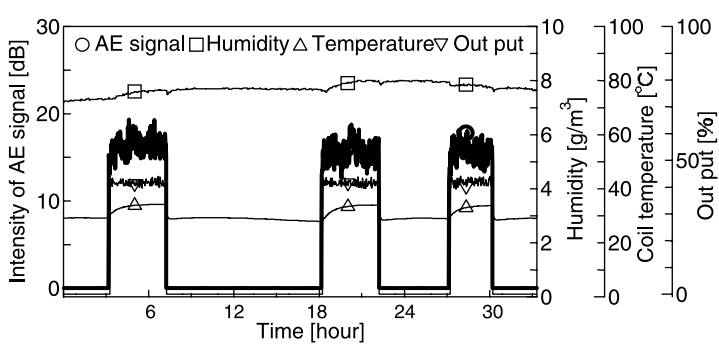

図 13 O-発電機オンライン測定時の 2 日間の $\mathrm{AE}$ 信号強度に及ぼす温度，湿度 そして出力の時系列特性

Fig. 13. Time dependence for intensity of AE signals, coil temperature, humidity and output percent for Ohydrogenerator for two days operation at on-line measurements.

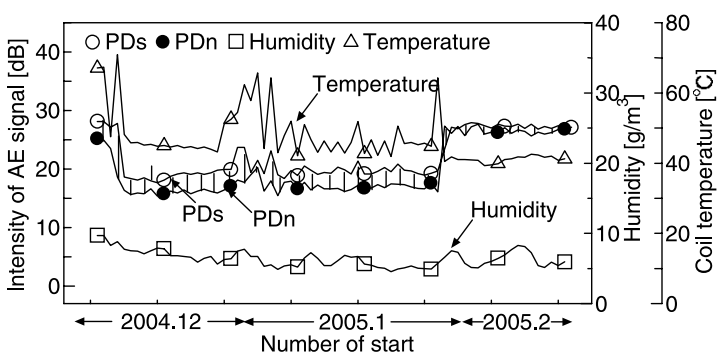

図 14 O-発電機オンライン測定時の PDs と $\mathrm{PDn}$ の 3 ケ月間 $\mathrm{AE}$ 信号強度に及ぼす 温度と湿度の時系列特性

Fig. 14. Time dependence for intensity of AE signals, coil temperature and humidity at PDs and PDn for Ohydrogenerator for three months at on-line measurements.

ることがわかる。

O-発電機の長期連続部分放電特性の一例を図 13 に示す。 この図からわかるように, PDは定常運転時においても 15 $19 \mathrm{~dB}$ の範囲内で変化することがわかる。さらに, 2004 年 12 月から 2005 年 2 月までの約 3 ケ月間の PD を PDs と PDn に分離して整理した結果の例を図 14 に示す。この図 から, O-発電機の場合, PDs と PDnは $15 \sim 25 \mathrm{~dB}$ の範囲 内で変化することがわかる。

$\mathrm{I}$-発電機と O-発電機の長期連続部分放電特性から PDs と PDn は運転環境に応じて複雑に変化することがわかった。 I-発電機の場合, 冷却方式が出口管通風形であるので, 固 定子巻線の部分放電特性は外部環境の影響を受けやすいと 考えられる。O-発電機に関する長期連続測定期間がまだ 3 カ月と短いので, 季節による部分放電特性の影響について は今後の研究課題である。

\section{4. まとめ}

水車発電機固定子巻線の絶縁状態監視保全を行うために, 運転条件と冷却方式が異なる水車発電機固定子巻線の部分 放電（PD）を長期に亘り測定した。本研究では, 複数個の $\mathrm{AE}$ センサを用いて実機の I- 発電機と O-発電機の 2 台（定 
格電圧 $11.0 \mathrm{kV}$ と $13.2 \mathrm{kV})$ を対象に，オフライン測定時に おける最大放電電荷量と $\mathrm{AE}$ 強度の関係を調べるとともに オンライン測定時における水車発電機固定子巻線の部分放 電特性に及ぼす出力，温度そして湿度の影響を調べた。主 な成果は次の通りである。

（1）各発電機において PD が発生している付近に複数 個の $\mathrm{AE}$ センサを固定して，部分放電試験の各印加電圧に 対して $\mathrm{AE}$ 信号測定を同時に行った。 $\mathrm{Qmax}=10,000 \mathrm{pC}$ における I-発電機の平均 $\mathrm{AE}$ 信号強度は $15.6 \mathrm{~dB}$ である。 $\mathrm{Qmax}=10,000 \mathrm{pC}$ における $\mathrm{O}$-発電機の平均 $\mathrm{AE}$ 信号強 度は $27.1 \mathrm{~dB}$ である。水車発電機の非破壊試験の結果より, Qmax と AE 信号強度には相関関係がある。

（2）各発電機においてオンライン測定時の水車発電機 固定子巻線の絶縁劣化の場所は TEAM ストレスを複合的 に受けて複雑に分布する。

（3） I-発電機の長期連続部分放電測定において，夏場と 冬場におけるオンライン測定の AE 信号強度に及ぼす温度, 湿度そして出力の時系列特性を調べた結果，夏場において 2004 年の夏の AE 信号強度レベルは 2003 年の值に比べて 約 $5 \mathrm{~dB}$ 程度の上昇を示すが，冬場における $\mathrm{AE}$ 信号強度の 変化がほとんど見られない。2004 年 12 月から 2005 年 2 月までの約 3 ケ月間の長期連続測定の結果, PDs と PDnは 26〜 $40 \mathrm{~dB}$ と変化する。

(4) O-発電機の長期連続部分放電測定において，2004 年 12 月から 2005 年 2 月までの約 3 ケ月間の長期連続測定 の結果，PDs と PDnは 15〜25 dB と変化する。

最後に, 本研究は宮崎公立大学と九州電力 (株) 宮崎支店 並びに宮崎公立大学と（株）興電舎との産学共同研究費に よって行われたことを記し関係者各位に謝意を表する。ま た，宮崎県企業局施設管理課の関係者各位にも感謝する。

(平成 17 年 8 月 19 日受付，平成 18 年 1 月 18 日再受付)

\section{文献}

(1) IEEE Trial-Use Guide to the Measurement of Partial Discharges in Rotating Machinery, IEEE Std 1434-2000

(2) T. Tsuji, T. Kaneko, Y.M. Sung, M. Otsubo, C. Honda, O. Takenouchi, K Yamatsu, and K. Tanaka: "On-line Partial Discharge Detection for WaterWheel Generator using Acoustic Emission Sensors", T. IEE Japan, Vol.112B, No.4, pp.513-519 (2002-4) (in Japanese)

辻 利則 - 金子正光 - 成 烈文 · 大坪昌久 - 本田親久 ·竹之内修 山津謙一・田中和洋：「AE センサを用いた水車発電機運転中 PD 測 定」, 電学論 B, 122, 4, pp.513-517 (2002-4)

(3) T. Kaneko, A. Takemura, O. Takenouchi, Y.M. Sung, M. Otsubo, C. Honda, Y. Tsuruta, and K. Tanaka :"On-line Partial Discharge Measurement of Hydrogenerator Stator Winding using Acoustic Emission Detection Techniques", IEEJ Trans. PE, Vol.124, No.2, pp.274-280 (2004-2)

(4) T. Kaneko, A. Takemura, O. Takenouchi, Y.M. Sung, M. Otsubo, C. Honda Y. Tsuruta, A. Fukura, and K. Tanaka: "Estimation of Position of On-line Partial Discharge on Hydrogenerator Stator Windings using Acoustic Emission Detection Techniques", IEEJ Trans. FM, Vol.124, No.7, pp.534-540 (2004-7)

(5) M. Kanegami, T. Okamoto, A. Shoji, T. Noda, K. Ebata, O. Hattori, K Shiraishi, and S. Sakata: "Continous Monitoring of Partical Discharge in Hydro Generator Stator Coil", Proc. of the 35th Symposium on Electrical and Electronic Insulating Materials and Applications in Systems, H-6, pp.165-168 (2004-11) (in Japanese)
金神雅樹・岡本達希・庄子 明・野田隆昌・江幡和德・服部 修 白石和樹・坂田里実:「水車発電機巻線の連続長期部分放電計測」, 第 35 回電気電子絶縁材料システムシンポジウム予稿集, H-6, pp.165-168 (2004-11)

(6) T. Ueda, T. Kaneko, O. Takenouchi, Y.M. Sung, M. Otsubo, C. Honda, Y. Tsuruta, A. Fukura, and K. Tanaka: "Detection of Position of On-line Maximum Partial Discharge on Hydrogenerator Stator Windings using Acoustic Emission Detection Techniques", Proc. of 12th Asian Conference on Electrical Discharge at Shenzhen, B3, pp.183-186, China (2004-11)

( 7 ) T. Kaneko, T. Ueda, O. Takenouchi, M. Otsubo, C. Honda, Y. Tsuruta, A. Fukura, and K. Tanaka: "Characteristics of On-line and Off-line Partial Discharge on Hydrogenerator Stator Windings using Acoustic Emission Detection Techniques", Proc. of 2005 International Symposium on Electrical Insulating Materials, A6-5, pp.837-840 (2005-6)

(8) T. Ueda, T. Fujii, T. Kaneko, O. Takenouchi, M. Otsubo, C. Honda, A. Fukura, T. Takatsuki, K. Tanaka, and Y. Tsuruta: "Characteristics of On-line Partial Discharge for Hydrogenerator Stator Windings using Acoustic Emission Detection Techniques [I]", Proc. of the Sixteenth Annual Conference of Power \& Energy Society, IEE Japan, No.339, pp.40-11 40-12 (2005-8) (in Japanese)

上田隆司 ·藤井太志 · 金子正光 ·竹之内 修 · 大坪昌久 - 本田親久 福良敦司・高月孝之・田中和洋・鶴田芳男：「超音波法による運転 中水車発電機固定子卷線の部分放電特性 $[I]\rfloor$, 平成 17 年電気学会電 カ・エネルギー部門大会, No.339, pp.40-11 40-12 (2005-8)

(9) M. Kanegami, T. Okamoto, K. Sado, T. Noda, K. Takimoto, and H. Sagara: "Partial Discharge Monitoring System with Use of Resistance Temperature Detector Laid in Hydro Power Generator Stator Coil Slot", The Papers of Technical Meeting on Dielectrics and Electrical Insulation, IEE Japan DEI01-50, pp.57-61 (2001) (in Japanese)

金神雅樹・岡本達希・佐渡清春 - 野田隆昌 - 滝本和彦・相良秀晃： 「温度センサを用いた水車発電機コイル用部分放電監視システム」 電気学会誘電・絶縁材料研資, DEI-01-50, pp.57-61 (2001)

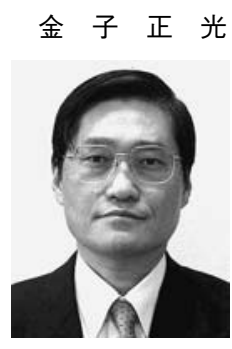

(正員) 1954 年生。1980 年 3 月九州大学大学院 工学研究科修士課程修了。同年 4 月九州大学工 学部助手，1988 年 4 月運輸省航空大学校助教授, 1993 年 4 月宮崎公立大学助教授を経て，1999 年 4 月同教授, 現在に至る。主として, 回転機器の 絶縁診断の研究と情報弱者に対する IT 教育支援 プログラムに関する研究に従事。工学博士。静電 気学会, 電子情報通信学会会員。

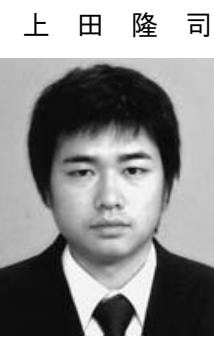

(正員) 1981 年生。 2003 年 3 月宮崎大学工学部 電気電子工学科卒業。同年 4 月宮崎大学大学院 工学研究科電気電子工学専攻博士課程前期課程入 学, 現在に至る。主として, 水車発電機の絶縁劣 化に関する研究に従事。

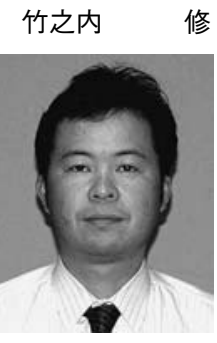

（正員） 1966 年生。1991 年 3 月宮崎大学大学院 工学研究科修士課程修了。同年 4 月長崎大学工 学部助手。1 1993 年 4 月運輸省航空大学校に勤務。 1997 年 3 月長崎大学大学院海洋生産科学研究科 博士課程修了。2001 年 4 月独立行政法人航空大 学校助教授, 現在に至る。博士 (工学)。主とし て高電圧現象の研究に従事。静電気学会, 航空宇 宙学会会員。 


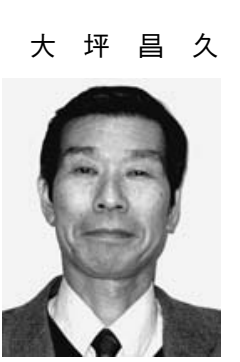

(正員) 1947 年生。1970 年 3 月宮崎大学工学部 専攻科電気工学専攻修了。同年 4 月宮崎大学工学 部助手, 2003 年同電気電子工学科教授, 現在に至 る。1994 年 5 月から米国 Clarkson 大学に研究留 学。工学博士。放電と応用, 電力工学及び燃料電 池・風力発電などの新エネルギーに関する研究に 従事。静電気学会, 応用物理学会, IEEE 会員。

本田親 久 (正員) 1943 年生。1 965 年 3 月九州大学工学部

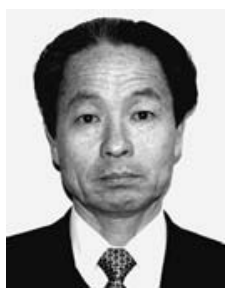
電気工学科卒業。同年 4 月同大学助手。1989 年 同大学大学院総合理工学研究科客員助教授を経て, 1993 年宮崎大学工学部電気電子工学科教授, 2005 年 10 月宮崎大学工学部長, 現在に至る。主とし て,レーザ応用プラズマ計測の研究に従事。工学 博士。放電学会, プラズマ核融合学会, 応用物理 学会, レーザー学会会員。

鶴 田 芳 男 (非会員) 1956 年生。1977 年都城工業高等専門

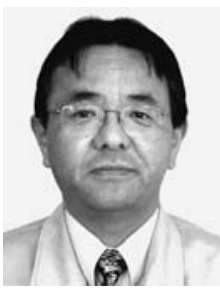

学校卒業。現在, (株) 興電舎代表取締社長。
岩 元 秀 樹 (非会員) 1977 年生。 2001 年九州電力（株）入

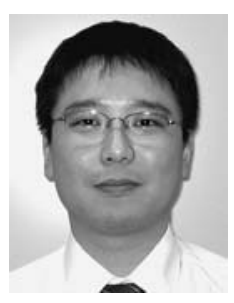
社。2004 年 8 月宮崎支店送変電統括部発変電グ ループ所属, 現在に至る。主として, 変電所の建 設，保守及び水力発電設備の技術開発に従事。

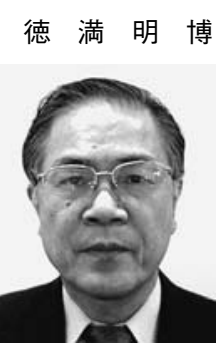

(非会員) 1949 年生。1968 年九州電力株式会社 入社。2005 年 7 月宮崎支店送変電統括部発変電 グループ長, 現在に至る。主として, 管内水力発 電所・変電所の保守, 運用の総合管理及び技術の 調查・研究並びに水力発電所の設計・施工管理に 従事。 